\title{
THE MECHANISMS OF ADAPTATION TO A CENTRAL VENOUS-ARTERIAL SHUNT
}

\author{
BY \\ P. H. DAVISON, G. H. ARMITAGE, AND W. MELVILLE ARNOTT
}

From the Department of Medicine, Queen Elizabeth Hospital, Birmingham

Received October 24, 1952

A central venous-arterial shunt consists essentially of the transfer of a proportion of the venous blood directly into the systemic arterial tree without passage through the pulmonary capillaries. Cyanosis of central origin is the major clinical manifestation and characteristically this is deepened by exertion and cannot be abolished by inhalation of pure oxygen. Some loss of exercise tolerance is invariably present, and when a high proportion of the venous return by-passes the pulmonary capillaries disability is severe and is associated with poor physical development.

While a great variety of congenital cardiac abnormalities may be accompanied by a central venous-arterial shunt from infancy, the tetralogy of Fallot is encountered most frequently. If the shunt first appears in later life it is often the result of progressive pulmonary hypertension superimposed upon a large septal defect. Pulmonary arterio-venous aneurysms are a rare cause of the condition, and are usually found with hereditary telangiectasia.

In recent years, wide interest in cyanotic congenital heart disease has been stimulated by the successful surgical treatment of the tetralogy of Fallot (Blalock and Taussig, 1945; Brock and Campbell, 1950). Accurate pre-operative diagnosis is essential, and physiological investigation by right heart catheterization has proved invaluable in doubtful cases (Bing et al., 1947a and $b$; Cournand et al., 1949; Holling and Zak, 1950). The data obtained in this way have made it possible to study the underlying mechanisms of adaptation to a central venous-arterial shunt (Bing et al., 1948; Burchell et al., 1950; Ernsting and Shephard, 1951).

The purpose of this study is to evaluate the mechanisms of adaptation to a central venousarterial shunt in the light of observations on patients with this condition.

\section{METHODS .}

Thirty-six patients were studied, of whom 32 had congenital heart disease and 4 pulmonary arteriovenous aneurysms. The cases were unselected, a central venous-arterial shunt being the only criterion for inclusion. Sex distribution was approximately equal and their ages ranged from 5 to 35 years. The severity of the disability varied from slight to almost complete incapacity.

Pulmonary stenosis was confirmed by measurement of pulmonary arterial and right ventricular pressures in 14 of the 18 cases with Fallot's tetralogy, and in the one with pulmonary stenosis and an atrial septal defect. Eisenmenger's syndrome was diagnosed in 6 patients after demonstrating a central venous-arterial shunt with gross rise of pulmonary arterial pressure; these probably included cases of septal defect with reversed shunt. Exploratory thoracotomy supported the diagnosis in 15 and in 2 it was confirmed at necropsy.

Diagnostic right-heart catheterization was employed in all but two of the series. Tea and toast was allowed two hours before the investigation, performed by the usual technique with the patient in the supine resting state under light barbiturate or rectal avertin sedation. Mixed venous blood samples were taken from the right atrium in all but one in whom anomalous pulmonary veins entering the superior vena cava necessitated use of the inferior vena caval sample. Arterial blood samples were taken through an indwelling brachial arterial needle during catheterization or by femoral arterial puncture immediately the catheter 
had been withdrawn. Intracardiac and pulmonary arterial pressures were measured with a saline manometer or mechano-electronic transducing manometer (Cumming et al., 1950) employing a Cossor oscilloscope and camera, and in later instances a Sanborn polyviso oscillograph.

The effect of exercise was studied in five cases, a bicycle ergometer being mounted to the foot of the screening table so that the patient could pedal whilst lying supine. The work which each could readily perform for five minutes without undue distress was determined before the investigation, and the rate of work was kept constant by synchronizing the ergometer with an electric motor. Approximately two minutes was allowed for stabilization, and brachial arterial and right atrial blood samples were taken simultaneously during the collection of expired air, which averaged two minutes.

The methods of Van Slyke and Neill were employed for gas analysis of blood samples; $p \mathrm{H}$ and $p \mathrm{CO}_{2}$ were not estimated. Oxygen consumption at rest and during standard exercise tests, minute ventilation, and R.Q. were estimated from Douglas bag collections of expired air. When a Tissot spirometer became available it was used as a reservoir and means of measuring inspired volumes, whilst Douglas bags were still employed for expired air collection; this was found preferable to collecting directly into the Tissot because it avoids the delay while the spirometer dead-space is washed out with expired air. Gas samples were analysed in the Sleigh apparatus, whose accuracy compares favourably with that of the Haldane. Gas volumes were corrected for temperature and barometer; oxygen consumption, etc. being recorded as dry volumes at $760 \mathrm{~mm}$. $\mathrm{Hg}, 0^{\circ} \mathrm{C}$. (NTP), and ventilation rates as volumes of saturated gas at $37^{\circ} \mathrm{C}$. and ambient pressure (BTPS).

Circulatory instability, frequently present in cyanotic heart disease, makes it desirable to investigate cardiac and respiratory functions simultaneously when their interrelationship is a subject of study. When technical difficulties prevented this the independent investigations were made, as far as possible, under the same conditions.

Blood flow was estimated by application of the direct Fick principle (Fick, 1870).

Effective pulmonary blood flow, i.e. the amount of mixed venous blood entering the pulmonary capillary bed, both directly and by way of collateral vessels, is given by the formula:

$$
\frac{\mathrm{O}_{2} \text { consumption (ml./min.) }}{\text { (pulmonary venous } \mathrm{O}_{2} \text { content }- \text { mixed venous } \mathrm{O}_{2} \text { content) }}
$$

The oxygen content of blood leaving the lungs (pulmonary venous blood) was presumed to be 95 per cent of the blood oxygen capacity in all but one subject in whom catheterization of a pulmonary vein made direct estimation possible; in formula (1) one can therefore substitute $\left(0.95 \times \mathrm{O}_{2}\right.$ capacity) for pulmonary venous $\mathrm{O}_{2}$ content.

Systemic blood flow, i.e. the amount of blood perfusing the systemic capillary bed, is given by the formula:

$$
\frac{\mathrm{O}_{2} \text { consumption }(\mathrm{ml} . / \mathrm{min} .)}{\left(\text { arterial } \mathrm{O}_{2} \text { content }- \text { mixed venous } \mathrm{O}_{2}\right.} \overline{\text { content })} \text {. }
$$

The central venous-arterial shunt, expressed as a percentage of the systemic flow, is given by the formula:

$$
100-\frac{\left(\text { arterial } \mathrm{O}_{2} \text { content }- \text { mixed venous } \mathrm{O}_{2} \text { content }\right)}{\left(0.95 \times \mathrm{O}_{2} \text { capacity }- \text { mixed venous } \mathrm{O}_{2} \text { content }\right)} \times 100
$$

Arterial and mixed venous blood oxygen tensions were calculated from the oxygen dissociation curve for human blood at $p \mathrm{H} 7 \cdot 40$ based upon the data of Dill (1944).

Mean systemic capillary oxygen tension, taken to represent " the oxygen pressure, which, if it prevailed throughout the entire length of all the capillaries of the body, would not alter the quantity of oxygen diffusing under actual physiological conditioms" (Houston and Riley, 1947), was estimated according to Barcroft's suggested approximation (1934) and is given by the formula:

$$
\text { Mixed venous } p \mathrm{O}_{2}+\left(\text { arterial } p \mathrm{O}_{2}-\text { mixed venous } p \mathrm{O}_{2}\right) / 3
$$

Respiratory studies on patients of this series have shown that the resting oxygen uptake lies within the predicted range of normality; therefore, to facilitate more detailed analysis of circulatory function, the observed arterio-venous oxygen difference has been employed to express the systemic and effective pulmonary blood flows of each patient as a percentage of the average normal resting value, where an arteriovenous oxygen difference of $4.40 \mathrm{ml}$. per $100 \mathrm{ml}$. of blood has been taken as the normal value for both systemic and effective pulmonary flow: Blood flow (per cent of normal) equals:

$$
\frac{4.40}{\mathrm{~A}-\mathrm{V} \mathrm{O}_{2} \text { diff. }} \times 100 \text {. . . . . . . . . . . . . . }
$$

The published findings of Bing et al. (1947b) upon 36 patients with the tetralogy of Fallot have also been analysed by these methods, and the results incorporated in the later section of this work. Their findings from blood-gas analysis follow the same pattern as our own, but we have been unable to confirm the depression of resting oxygen uptake observed in many of their cases.

The influence of the hæmoglobin content of the blood (where 100 per cent hæmoglobin is equivalent to 
20 volumes per cent $\mathrm{O}_{2}$ capacity) upon the percentage oxygen saturation of mixed venous blood and the mean systemic capillary oxygen tension has been predicted at different levels of effective pulmonary blood flow by application of the following formulæ, which presume a normal resting oxygen uptake and normal resting systemic blood flow: Effective pulmonary blood flow (percentage of normal) equals:

$$
\frac{4.40}{\mathrm{O}_{2} \text { capacity } \times \frac{\left(95-\text { percentage } \mathrm{O}_{2} \text { sat. mix. ven. blood }\right)}{100}} \times 100 \text {. . . . . . }
$$

Percentage $\mathrm{O}_{2}$ sat. arterial blood equals:

$$
\text { Percentage } \mathrm{O}_{2} \text { sat. mix. ven blood }+\frac{4.40}{\mathrm{O}_{2} \text { capacity }} \times 100 \text {. . . . . . . }
$$

Mean systemic capillary oxygen tension is then predicted from formula (4).

Employing formula (6), curves have been plotted (Fig. 3) to show the relationship between effective pulmonary blood flow and the percentage oxygen saturation of mixed venous blood at different hæmoglobin levels. Employing formulæ (6), (7), and (4), curves have been plotted (Fig. 2) to show the relationship between effective pulmonary blood flow and mean systemic capillary oxygen tension at different hæmoglobin levels.

The methods used in the analysis of respiratory function are discussed in the section on respiratory behaviour.

\section{RESULTS}

Details of the findings are shown in Table I. Oxygen capacity of the blood showed a wide variation with a mean of $24 \cdot 1 \pm 0.9$ vols. per $100 \mathrm{ml}$. Arterial oxygen saturation was invariably depressed, with a mean value of 76 per cent. Arterial carbon dioxide content was below normal in every case. Mixed venous oxygen saturation was also reduced in most patients.

The systemic arterio-venous oxygen difference lay within the limits of normal in all but six patients and the mean value of $4 \cdot 3 \pm 0 \cdot 2$ vols. per $100 \mathrm{ml}$. approximates closely to the normal.

The effective pulmonary arterio-venous oxygen difference lay above the upper limit of normal in all but four cases, and the mean value of $8.94 \pm 0.55$ volumes per $100 \mathrm{ml}$. is equivalent to an effective pulmonary flow 49 per cent of the normal. The venous-arterial shunt showed wide variation with a mean value of 47 per cent of the systemic blood flow. Mean systemic capillary oxygen tension was consistently depressed and the mean value of $35.2 \pm 1.0 \mathrm{~mm}$. $\mathrm{Hg}$ is $20 \mathrm{~mm}$. below the average normal value.

Comparison of the effective pulmonary arterio-venous oxygen difference in patients with Fallot's tetralogy and Eisenmenger's syndrome shows no significant difference; therefore, the size of the effective pulmonary flow is no guide to the pulmonary arterial pressure, since it may be greatly curtailed in the presence of extreme pulmonary hypertension.

The mean values for both systemic and effective pulmonary arterio-venous oxygen differences were lowest in patients with congenital pulmonary telangiectasia. Therefore, as a group, these cases showed the least depression of effective pulmonary flow with a moderate but constant increase in systemic flow.

There was evidence of gross hæmodynamic instability during investigation of three patients with Fallot's tetralogy. In two (Cases 4 and 14), considerable fluctuation of exercise tolerance was noted clinically, and cyanotic episodes with loss of consciousness frequently occurred in the latter. Both exhibited increasing cyanosis and sinus tachycardia during investigation, and intra-arterial pressure records taken in Case 14 showed marked reduction of the systemic blood pressure. The low arterial oxygen saturations observed, produced by a large central venous arterial shunt in each case, were inconsistent with the moderate reduction of effective pulmonary flow. In the third (Case 6) exercise tolerance showed little variation and the hæmodynamic instability was probably due to leaving the cardiac catheter for too long (10 to 15 minutes) within the stenosed right ventricular outflow tract.

The remainder showed no evidence of instability during investigation, and the values obtained are considered representative of their normal resting state. 
TABLE I

Arterial Oxygen and Carbon Dioxide Percentages and Veno-Arterial Shunt

\begin{tabular}{l|c|c|c|c|c|c|c|c}
\hline $\begin{array}{l}\text { Case } \\
\text { No. }\end{array}$ & $\begin{array}{c}\text { Oxygen } \\
\text { capacity } \\
\text { (vol./100 ml.) }\end{array}$ & $\begin{array}{c}\text { Arterial } \\
\text { CO } \\
\text { content } \\
\text { (vol./100 ml.) }\end{array}$ & $\begin{array}{c}\text { Arterial } \\
\mathbf{O}_{2} \\
\text { percentage } \\
\text { saturation }\end{array}$ & $\begin{array}{c}\text { Mixed } \\
\text { venous } \\
\text { percentage } \\
\mathbf{O}_{2} \\
\text { saturation }\end{array}$ & $\begin{array}{c}\text { Mean } \\
\text { systemic } \\
\text { capillary } \\
\text { oxygen } \\
\text { tension } \\
\text { (mm. Hg) }\end{array}$ & $\begin{array}{c}\text { Effective } \\
\text { pulmonary } \\
\text { A-V O } \\
\text { difference }\end{array}$ & $\begin{array}{c}\text { Systemic } \\
\text { A-V O } \\
\text { difference }\end{array}$ & $\begin{array}{c}\text { V-A shunt } \\
\text { percentage } \\
\text { of } \\
\text { systemic } \\
\text { flow }\end{array}$ \\
\hline
\end{tabular}

Tetralogy of Fallot

\begin{tabular}{|c|c|c|c|c|}
\hline $\begin{array}{l}1 \\
2 \\
3 \\
4 \\
5 \\
6\end{array}$ & $\begin{array}{l}23 \cdot 6 \\
22 \cdot 8 \\
23 \cdot 3 \\
24 \cdot 5 \\
19 \cdot 5 \\
26 \cdot 1 \\
28 \cdot 0\end{array}$ & $\begin{array}{l}\overline{40.9} \\
42.3 \\
40.7 \\
40.8 \\
37.7 \\
37.0\end{array}$ & $\begin{array}{l}\overline{81} \\
77 \\
76 \\
72 \\
27\end{array}$ & $\begin{array}{l}53 \\
59 \\
58 \\
58 \\
62 \\
59 \\
20\end{array}$ \\
\hline $\begin{array}{r}7 \\
8 \\
9 \\
10 \\
11 \\
12 \\
13 \\
14 \\
15 \\
16 \\
17 \\
18\end{array}$ & $\begin{array}{l}21 \cdot 7 \\
30 \cdot 4 \\
18.2 \\
19.7 \\
31.9 \\
23 \cdot 4 \\
21.7 \\
15.8 \\
27.5 \\
24 \cdot 5 \\
29 \cdot 3 \\
32 \cdot 3\end{array}$ & $\begin{array}{l}30.0 \\
35.5 \\
30.4 \\
36.7 \\
43.9 \\
38.1 \\
40 \cdot 2 \\
38.5 \\
42.6 \\
39.1 \\
38.3 \\
37.1 \\
32.9\end{array}$ & $\begin{array}{l}10 \\
82 \\
81 \\
91 \\
87 \\
73 \\
75 \\
84 \\
66 \\
65 \\
81 \\
79 \\
82\end{array}$ & $\begin{array}{l}65 \\
64 \\
65 \\
65 \\
61 \\
63 \\
66 \\
65 \\
57 \\
53 \\
69 \\
68\end{array}$ \\
\hline $\begin{array}{l}\text { Mean } \\
\text { S.D. } \\
\text { S.E.M. }\end{array}$ & $\begin{array}{r}24 \cdot 4 \\
4 \cdot 3 \\
1.0\end{array}$ & $\begin{array}{r}38.5 \\
3.2 \\
0.8\end{array}$ & $\begin{array}{r}78 \\
7 \\
2\end{array}$ & $\begin{array}{r}62 \\
4 \\
1\end{array}$ \\
\hline
\end{tabular}

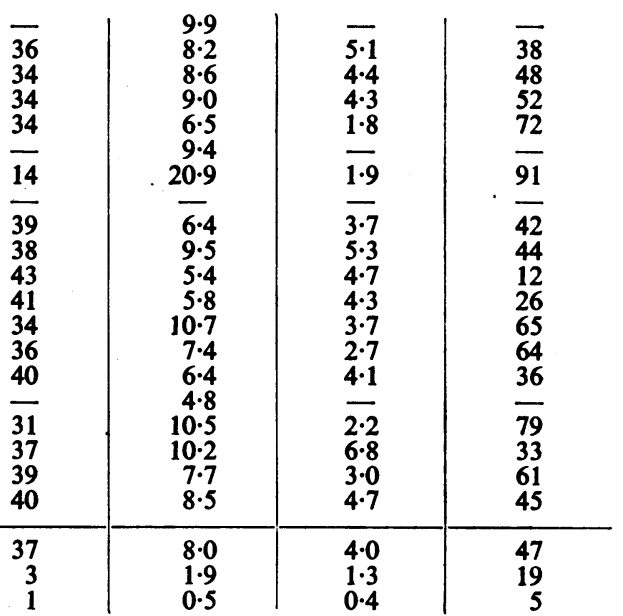

Eisenmenger complex

\begin{tabular}{|c|c|c|c|c|c|c|c|c|}
\hline $\begin{array}{l}19 \\
20 \\
21 \\
22 \\
23 \\
24\end{array}$ & $\begin{array}{l}23.4 \\
16.1 \\
23.7 \\
13.6 \\
28.6 \\
27.2\end{array}$ & $\begin{array}{c}39 \cdot 3 \\
\overline{7} \\
39 \cdot 4 \\
34 \cdot 2 \\
38 \cdot 3\end{array}$ & $\begin{array}{l}79 \\
75 \\
74 \\
75 \\
80 \\
88\end{array}$ & $\begin{array}{l}59 \\
55 \\
47 \\
46 \\
64 \\
68\end{array}$ & $\begin{array}{l}35 \\
33 \\
30 \\
30 \\
37 \\
42\end{array}$ & $\begin{array}{r}8.5 \\
6.5 \\
11.3 \\
6.7 \\
8.9 \\
9.5\end{array}$ & $\begin{array}{l}4.8 \\
3.3 \\
6.5 \\
4.0 \\
4.8 \\
7.5\end{array}$ & $\begin{array}{l}43 \\
49 \\
43 \\
40 \\
46 \\
21\end{array}$ \\
\hline $\begin{array}{l}\text { Mean } \\
\text { S.D. } \\
\text { S.E.M. }\end{array}$ & $\begin{array}{r}22 \cdot 3 \\
6 \cdot 1 \\
2 \cdot 7\end{array}$ & $\begin{array}{c}37.7 \\
2.9 \\
1.72\end{array}$ & $\begin{array}{r}81 \\
3 \\
1\end{array}$ & $\begin{array}{r}56 \\
8 \\
3\end{array}$ & $\begin{array}{r}35 \\
3 \\
1\end{array}$ & $\begin{array}{l}8.6 \\
1.9 \\
0.9\end{array}$ & $\begin{array}{l}5.1 \\
1.2 \\
0.5\end{array}$ & $\begin{array}{r}40 \\
3 \\
1.5\end{array}$ \\
\hline
\end{tabular}

Pulmonary telangiectasia

\begin{tabular}{|c|c|c|c|c|c|c|c|c|}
\hline $\begin{array}{l}25 \\
26 \\
27 \\
28\end{array}$ & $\begin{array}{l}21 \cdot 1 \\
16.5 \\
29 \cdot 0 \\
14.2\end{array}$ & $\begin{array}{l}43 \cdot 7 \\
43 \cdot 5 \\
36 \cdot 1 \\
46 \cdot 3\end{array}$ & $\begin{array}{l}90 \\
72 \\
81 \\
64\end{array}$ & $\begin{array}{l}71 \\
49 \\
69 \\
48\end{array}$ & $\begin{array}{l}46 \\
30 \\
39 \\
28\end{array}$ & $\begin{array}{l}5.0 \\
7.6 \\
7.6 \\
6.7\end{array}$ & $\begin{array}{l}3.4 \\
3.8 \\
3.5 \\
2.4\end{array}$ & $\begin{array}{l}21 \\
50 \\
54 \\
64\end{array}$ \\
\hline $\begin{array}{l}\text { Mean } \\
\text { S.D. } \\
\text { S.E.M. }\end{array}$ & $\begin{array}{r}20.2 \\
6.5 \\
3.3\end{array}$ & $\begin{array}{r}42 \cdot 4 \\
4 \cdot 4 \\
2 \cdot 2\end{array}$ & $\begin{array}{r}77 \\
11 \\
5\end{array}$ & $\begin{array}{r}59 \\
12 \\
6\end{array}$ & $\begin{array}{r}36 \\
8 \\
4\end{array}$ & $\begin{array}{l}6.7 \\
1.2 \\
0.6\end{array}$ & $\begin{array}{l}3.4 \\
0.7 \\
0.3\end{array}$ & $\begin{array}{r}47 \\
18 \\
9\end{array}$ \\
\hline
\end{tabular}

\begin{tabular}{|c|c|c|c|c|c|c|c|c|}
\hline \multicolumn{9}{|c|}{ Miscellaneous } \\
\hline $\begin{array}{l}29 \\
30 \\
31 \\
32 \\
33 \\
34\end{array}$ & $\begin{array}{l}28.8 \\
27.9 \\
30 \cdot 4 \\
24 \cdot 3 \\
26 \cdot 3 \\
33.9\end{array}$ & $\begin{array}{l}44.5 \\
36.9 \\
34 \cdot 6 \\
40.9 \\
31 \cdot 6\end{array}$ & $\begin{array}{l}59 \\
75 \\
48 \\
84 \\
69\end{array}$ & $\begin{array}{l}41 \\
56 \\
35 \\
66 \\
45 \\
50\end{array}$ & $\begin{array}{l}25 \\
33 \\
22 \\
39 \\
29\end{array}$ & $\begin{array}{r}15.5 \\
10.9 \\
18.3 \\
7.6 \\
13.2 \\
15.4\end{array}$ & $\begin{array}{l}5.2 \\
5.4 \\
3.9 \\
4.4 \\
6.5\end{array}$ & $\begin{array}{l}67 \\
50 \\
78 \\
42 \\
58\end{array}$ \\
\hline $\begin{array}{l}\text { Mean } \\
\text { S.D. } \\
\text { S.E.M. }\end{array}$ & $\begin{array}{r}28.6 \\
3.4 \\
1.4\end{array}$ & $\begin{array}{r}37 \cdot 7 \\
5.1 \\
2 \cdot 3\end{array}$ & $\begin{array}{r}67 \\
14 \\
6\end{array}$ & $\begin{array}{r}48 \\
11 \\
4\end{array}$ & $\begin{array}{r}30 \\
7 \\
3\end{array}$ & $\begin{array}{r}13.5 \\
3.8 \\
1.5\end{array}$ & $\begin{array}{l}5.1 \\
0.9 \\
0.4\end{array}$ & $\begin{array}{r}59 \\
14 \\
6\end{array}$ \\
\hline
\end{tabular}

Mean values for the whole series

\begin{tabular}{c|r|r|r|r|r|r|r|r|r|} 
Mean & 24.2 & 38.7 & 76 & 58 & 35 & 8.9 & $4 \cdot 3$ & 47 \\
S.D.D. & 5.2 & 3.8 & 9 & 9 & 5 & 3.1 & 1.2 & 16 \\
S.E. & 0.9 & 0.7 & 2 & 1 & 1 & 0.5 & 0.2 & 3
\end{tabular}


The results of the respiratory function tests are discussed in the sections devoted to respiratory behaviour.

\section{Discussion}

A central venous-arterial shunt impairs the efficiency of oxygen transport from lungs to tissue in two ways, both of which are independent of the precise cardiac abnormality: (1) the patient's capacity to absorb oxygen is limited by the reduced venous inflow to the lungs; and (2) the oxygen tension of arterial blood supplied to the tissues is depressed by venous admixture.

Theoretically, adaptation to the state of subnormal effective pulmonary blood flow could occur by reduction of oxygen utilization, increase in arterio-venous oxygen difference (where " arterio" refers to pulmonary venous blood), and increase in hæmoglobin concentration. Increase in systemic blood flow can be regarded as an adaptation only when accompanied by increase in effective pulmonary flow. Adaptation by depression of oxygen content of mixed venous blood is restricted by the necessity of maintaining capillary oxygen tension at a level sufficient to enable oxygen to diffuse into the tissues. Extreme polycythæmia carries the disability of high viscosity.

\section{RESTING OXYGEN CONSUMPTION}

The question must first be faced as to the normality or otherwise of basal oxygen consumption in these conditions. In conformity with previous work (Holling and Zak, 1950; Burchell et al., 1950; Ernsting and Shephard, 1951) it was found to be normal, but Bing et al. (1947b) in their pioneer survey of 36 cases of Fallot's tetralogy, found low figures for B.M.R. in 34, with values as low as 48 and 46 per cent. They attribute this depression to chronic anoxia (though in fact there is little evident correlation within their series between B.M.R. and arterial oxygen saturation), and they stated their intention of publishing evidence that the effect of the Blalock operation was to elevate the B.M.R. where it was depressed. Their results and inferences imply such a bankruptcy of the oxygen economy as would make it idle to discuss adaptations to anoxia in this or related conditions.

In this series three considerations prevented estimates of what might be represented as B.M.R. These were: (1) the frequent discrepancy between actual and apparent age, which would render suspect the normal standard for heat production; (2) the extreme instability of R.Q. level which marks these cases (and may be due to a predominance in them of the anoxic stimulus to respiration permitting excessive irregularities of ventilation); and (3) the likelihood that those precautions necessary to ensure basal conditions in adults would have the reverse effect on apprehensive children. In the main these factors would tend to raise apparent B.M.R.; and since no specific measures to overcome their effect seems to have been taken by Bing's group, their results are the more surprising.

Instead of B.M.R. determinations on these cases (which were thought likely to be misleading on these grounds) respiratory exchange was determined under near-basal conditions standard in this laboratory. Comparison of the results was therefore possible with those of a control group from records selected only by the exclusion of known cases of anoxæmia or metabolic disorder. Age and sex differences were taken into account by multiplying each observed oxygen consumption in both groups by a factor that in effect projected it into an arbitrary standard age (18) and sex (male). The factor was obtained from the Boothby and Sandiford (1920) revision of Dubois' tables for normal heat production at all ages in each sex, the figure appropriate to the individual being divided by the figure for a male of 18 years.

Results. The composition of the groups and the significance of the differences between them are summarized in Table II. The average observed oxygen consumption figures for the cyanotic group are significantly higher than the corresponding control averages; but with the age influence eliminated in the standardized figures the differences though unchanged in sign are far below the accepted significance level. Had our cyanotic group been divided into Fallot cases and others, the eleven Fallot cases would give an average standardized uptake of $155.6 \mathrm{ml}$. of oxygen per minute which is, in fact, closer to the whole-group average than the male and female averages show.

In five of the cases of Fallot's tetralogy the oxygen consumption was again measured after Blalock operation, and in none was the change significant. Oxygen consumption rose in 4 patients on whom data were obtained two to three weeks after operation, but in each case the result was a more abnormal figure. Approximately three months after operation, however, all five had figures nearer to the control averages than before operation, and this change represented a fall in four cases and a rise in one. 
TABLE II

Comparison of Mean Oxygen Consumption at Rest in (A) 18 Cases of Cyanotic Congenttal Heart Disease, and (B) 23 Ordinary Hospital Patients without Cyanosis

\begin{tabular}{|c|c|c|c|c|c|c|c|c|c|c|}
\hline \multirow{3}{*}{\multicolumn{2}{|c|}{ Group }} & \multirow{3}{*}{$\begin{array}{c}\text { No. } \\
\text { of } \\
\text { subjects }\end{array}$} & \multicolumn{2}{|c|}{ Age } & \multicolumn{6}{|c|}{ Resting $\mathrm{O}_{2}$ uptake (c.c./M²/min.) } \\
\hline & & & \multirow{2}{*}{ Mean } & \multirow{2}{*}{ Range } & \multicolumn{3}{|c|}{ Observed } & \multicolumn{3}{|c|}{$\begin{array}{l}\text { Standardized to } \\
\text { age } 18 \text {, male sex }\end{array}$} \\
\hline & & & & & Mean & S.D. & Range & Mean & S.D. & Range \\
\hline $\begin{array}{l}\mathbf{A} \\
\text { Cyanotic congenital } \\
\text { cardiac disease }\end{array}$ & 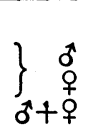 & $\begin{array}{r}11 \\
7 \\
18\end{array}$ & $\begin{array}{l}19 \cdot 2 \\
13 \cdot 5 \\
17.0\end{array}$ & $\begin{array}{l}7-33 \\
7-35 \\
7-35\end{array}$ & $\begin{array}{l}164 \cdot 2 \\
160 \cdot 3 \\
162 \cdot 7\end{array}$ & $\begin{array}{l} \pm 26 \\
\pm 24 \\
\pm 25\end{array}$ & $\begin{array}{l}126-220 \\
130-190 \\
126-220\end{array}$ & $\begin{array}{l}158.1 \\
154.9 \\
156.7\end{array}$ & $\begin{array}{l} \pm 16 \\
\pm 22 \\
\pm 17\end{array}$ & $\begin{array}{l}138-181 \\
122-178 \\
122-181\end{array}$ \\
\hline $\begin{array}{l}\text { B } \\
\text { Subjects free from } \\
\text { arterial anoxæmia }\end{array}$ & \} $\begin{aligned} 0 \\
0 \\
0 \\
0+9\end{aligned}$ & $\begin{array}{l}13 \\
10 \\
23\end{array}$ & $\begin{array}{l}36 \\
36 \\
36\end{array}$ & $\begin{array}{l}11-62 \\
24-48 \\
11-62\end{array}$ & $\begin{array}{l}143 \cdot 5 \\
127 \cdot 4 \\
136 \cdot 5\end{array}$ & $\begin{array}{r} \pm 16 \\
\pm 8 \\
\pm 17\end{array}$ & $\begin{array}{l}121-188 \\
118-141 \\
118-188\end{array}$ & $\begin{array}{l}153.4 \\
153.5 \\
153.4\end{array}$ & $\begin{array}{r} \pm 10 \\
\pm 10 \\
\pm 9\end{array}$ & $\begin{array}{l}138-168 \\
136-166 \\
136-168\end{array}$ \\
\hline
\end{tabular}

\begin{tabular}{|c|c|c|c|c|}
\hline & & $\sigma$ & q & $\sigma+o$ \\
\hline $\begin{array}{l}\text { Mean observed } \\
\mathrm{O}_{2} \text { uptake }\end{array}$ & $\frac{\text { Diff. A-B }}{\text { S.E. diff. }}$ & $\frac{20 \cdot 7}{9 \cdot 0}=2 \cdot 30$ & $\frac{32.9}{9 \cdot 5}=3.46$ & $\frac{26 \cdot 0}{6 \cdot 9}=3 \cdot 77$ \\
\hline $\begin{array}{l}\text { Mean standardized } \\
\mathrm{O}_{2} \text { uptake }\end{array}$ & $\frac{\text { Diff. A-B }}{\text { S.E. diff. }}$ & $\frac{4 \cdot 7}{5 \cdot 6}=0.84$ & $\frac{1.4}{8.9}=0.16$ & $\frac{3 \cdot 3}{5 \cdot 7}=0.58$ \\
\hline
\end{tabular}

\section{INCREASE IN HAMOGLOBIN}

In 32 patients investigated by cardiac catheterization the effective pulmonary blood flow has been expressed as a percentage of the average normal value (formula 5), and the figures obtained plotted against their oxygen capacities. The findings in 36 cases of Fallot's tetralogy reported by Bing et al., 1947b, have been similarly treated. The results are shown in Fig. 1. A highly significant negative correlation exists for each group (personal series (32), $\mathrm{r}$ equals 0.894; Bing's series (36), $\mathrm{r}$ equals 0.917 ; combined series (68), $\mathrm{r}$ equals 0.882 ). These statements are based upon the evidence that the resting oxygen consumption is normal.

The size of the effective pulmonary flow is then expressed by the recipracal value of its arteriovenous oxygen difference; since the pulmonary venous oxygen content is taken to be 95 per cent of the oxygen capacity, the arterio-venous difference then becomes a function of the percentage oxygen saturation and the oxygen capacity of the mixed venous blood (formulæ 6).

When the effective pulmonary blood flow is diminished, oxygen uptake from the lungs can only be maintained by a proportionate increase in the oxygen absorptive capacity of the mixed venous blood, and this can be achieved either by reduction of its oxygen saturation or increase of its oxygen capacity (i.e. hæmoglobin content) or a combination of the two. Reduction of oxygen saturation is the obvious and immediate method of compensating for decreased flow. The relationship which must exist between effective pulmonary flow and oxygen saturation (as percentage) of mixed venous blood, to permit a normal supply of oxygen to the tissues has been predicted (formula 6) and plotted in Fig. 3. When the oxygen-carrying power of the blood is normal (100 per cent hæmoglobin equivalent to 20 vols. $\mathrm{O}_{2}$ per $100 \mathrm{ml}$.) it is apparent from the shape of the curve that this mechanism alone adequately compensates for moderate reduction of the flow, but severe limitation would necessitate a fall in venous oxygen saturation to levels probably incompatible 
with normal metabolism. Thus reduction of effective pulmonary flow to three-quarters of the average normal value is met by a fall of venous saturation from 73 to 68 per cent, while with a half-normal flow venous saturation falls to 53 per cent, and one-quarter of the normal necessitates a saturation of only 11 per cent. Some additional mechanism is clearly essential if a workable capillary $\mathrm{O}_{2}$ tension is to be maintained at low rates of pulmonary blood flow.

The influence of the oxygen-carrying power of the blood upon this relationship is shown by curves plotted for hæmoglobin values of $75,125,150,175$, and 200 per cent. It is apparent that decreased hæmoglobin depresses the normal curve and shifts it to the left; increased hæmoglobin

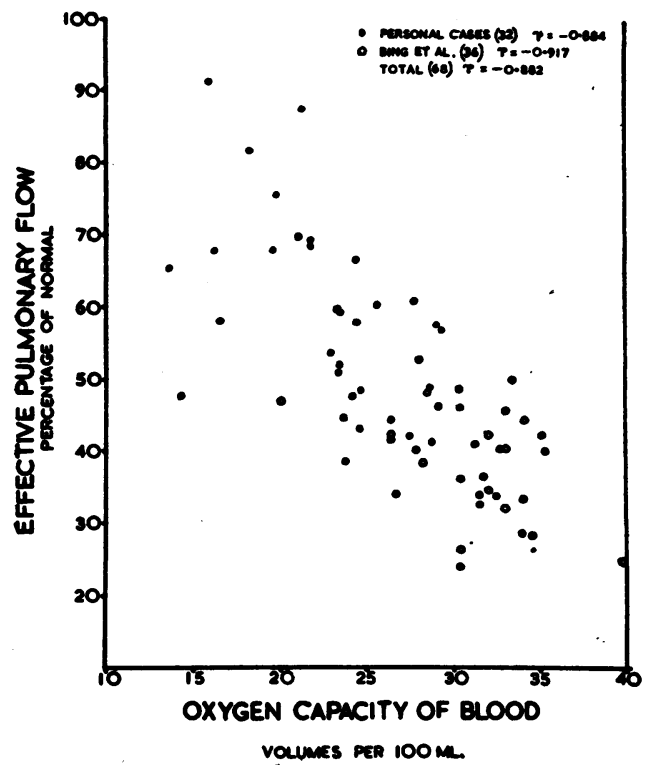

FIG. 1.-The relationship of effective pulmonary flow to the oxygen capacity of the blood.

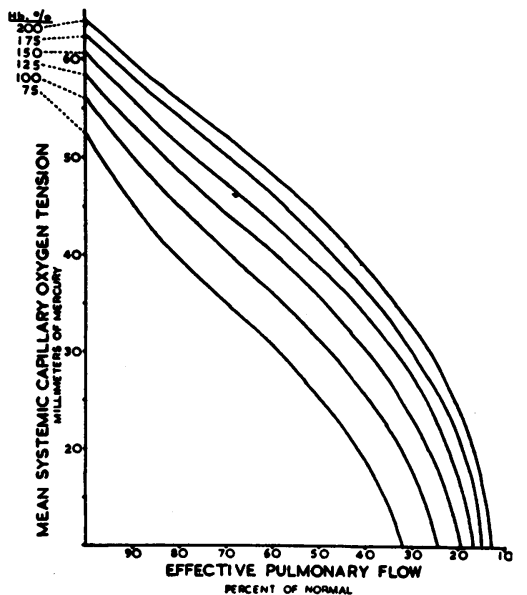

Fig. 2.-Curves showing the effect of different hæmoglobin levels on the relationship of the mean systemic capillary oxygen tension and the effective pulmonary flow (see Fig. 3).

elevates the curve and shifts it to the right, thereby delaying the point at which a precipitous fall in venous saturation must occur. An increased hæmoglobin produces only a slight elevation of venous saturation when the flow is normal or moderately reduced, while the effect on the saturation of hæmoglobin increment is progressively enhanced as the flow diminishes; thus, when the flow is three-quarters of the normal, hæmoglobin increments from 100 to 125,150 , and 175 per cent raise the venous saturation from 68 per cent to 73,76 , and 78 per cent respectively, while the same increments raise the saturation from 11 per cent to 27,38 , and 47 per cent respectively when the flow is reduced to one-quarter of the normal. It is clear, moreover, that there is a decreasing gain in venous saturation with each successive equal increment of hæmoglobin.

In Fig. 3 the observed percentage saturation of mixed venous blood has been plotted against the effective pulmonary blood flow in 68 patients and superimposed upon the predicted relationships for different hæmoglobin values, thus demonstrating that increased hæmoglobin does, in fact, prevent gross depression of venous saturation when the effective flow is greatly reduced.

It follows from this analysis that the resting oxygen uptake is maintained in the presence of a reduced effective pulmonary blood flow by two complementary mechanisms-(1) reduced percentage oxygen saturation of mixed venous blood and (2) increased hæmoglobin content. It is suggested that their integration determines the negative correlation between effective pulmonary blood flow and oxygen capacity of the blood. 


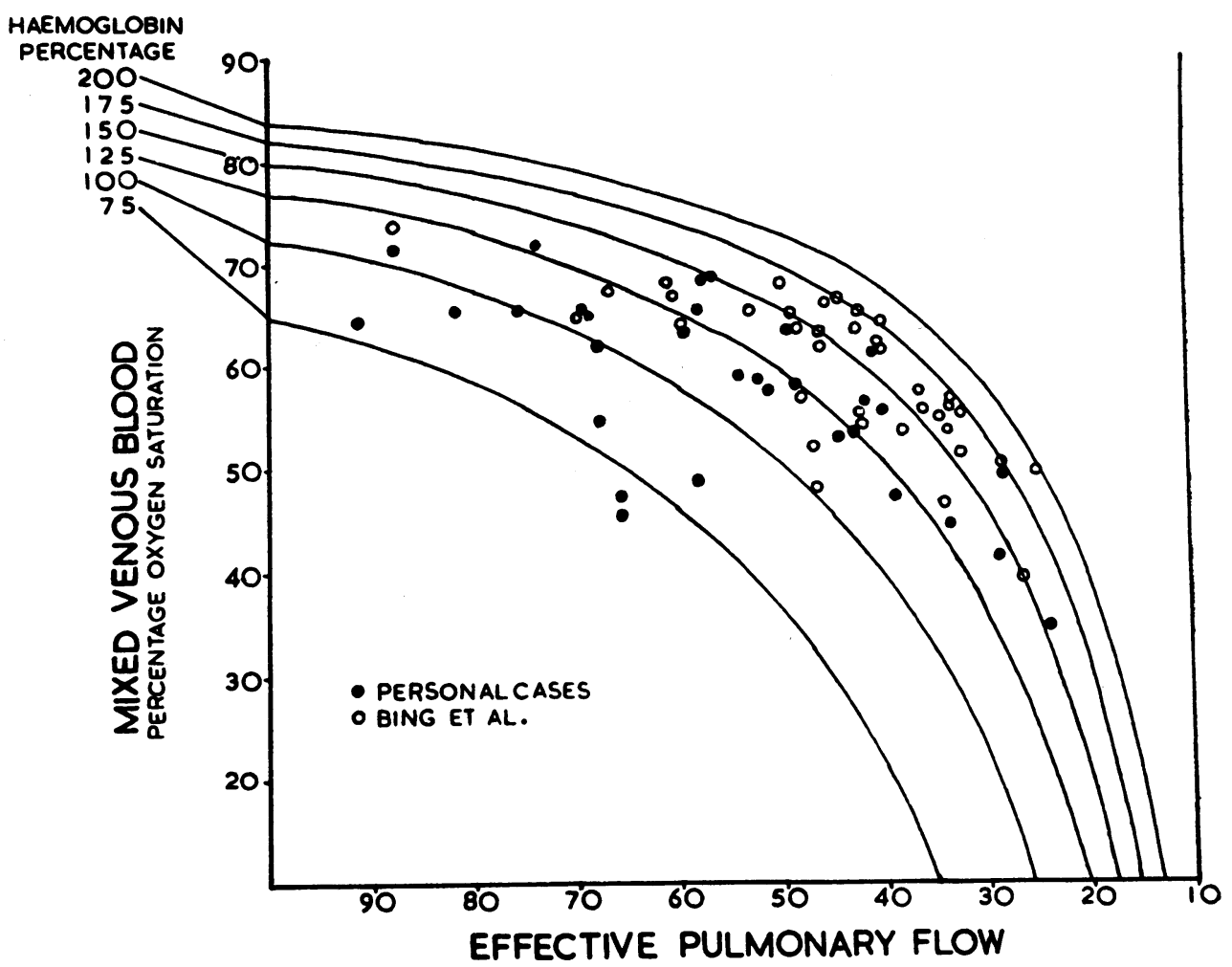

PERCENTAGE OF NORMAL

FIG. 3. - The effect of varying hæmoglobin percentages on the relationship between the percentage of oxygen saturation in mixed venous blood and the effective pulmonary flow.

\section{Tissue OXYgen Tension}

The mean systemic capillary oxygen tension and the consequent pressure gradient between capillary and cell govern the diffusion rate upon which depends the oxygen tension prevailing in the tissues; the diffusion gradient is relatively constant under the stable conditions of resting oxygen requirements and thus capillary and tissue oxygen tensions have a linear relationship.

Arterial oxygen tension is greatly reduced by a central venous-arterial shunt. The normal values for arterial oxygen saturation and tension lie upon the flat upper portion of the oxygen dissociation curve and therefore a small reduction of saturation-consequent upon venous admixture-is accompanied by considerable reduction of tension. On the other hand, the normal values for mixed venous oxygen saturation and tension lie upon the steep central portion of the dissociation curve and an equivalent reduction of venous saturation produced a much smaller fall in tension. Consequently, the gradient of oxygen tension between arterial and mixed venous blood is greatly reduced by the shunt, and the mean systemic capillary oxygen tension lies very close to that of mixed venous blood. Clearly, the shape of the normal oxygen dissociation curve is most important in preventing profound depression of tissue oxygen tension in these cases (Bing et al., 1948; Ernsting and Shephard, 1951) but this factor is fundamental rather than adaptive since it entails no modification of a normal physiological relationship.

As shown, the percentage oxygen saturation of mixed venous blood is determined by its oxygencarrying power and the size of the effective pulmonary blood flow, and may be predicted from 
any relationship between these two variables; therefore, a change in the volume of the systemic blood flow without concomitant alteration in the volume of the effective pulmonary blood flow cannot influence the percentage oxygen saturation of the mixed venous blood. Under these conditions the percentage oxygen saturation of arterial blood is a function of the mixed venous oxygen saturation (prefixed) and the coefficient of oxygen utilization of the tissues. In predicting the influence of the hæmoglobin value upon the mean systemic capillary oxygen tension a normal systemic blood flow has been presumed because the mean value for the systemic arterio-venous oxygen difference observed in patients investigated (4.34 vols. per $100 \mathrm{ml}$.) lies very close to the average normal value. The relationship between effective pulmonary flow and percentage oxygen saturation of mixed venous blood at any hæmoglobin level has already been discussed and is obtained from formula 6 . The percentage oxygen saturation of arterial blood is obtained from formula 7 , and mean systemic capillary oxygen tension calculated from formula 4 . Thus mean systemic capillary oxygen tension may be plotted against the effective pulmonary blood flow for any given value of hæmoglobin.

This approach is preferred to that employed by Bing et al. (1948), who calculated the gain in tissue oxygen tension due to increased hæmoglobin by subtracting a normal coefficient of oxygen utilization and one modified by the observed hæmoglobin value from the observed percentage oxygen saturation of the arterial blood. The difference between the mean systemic capillary oxygen tensions calculated from these two values of mixed venous saturation was taken to represent the gain (or loss) in oxygen tension directly attributable to the hæmoglobin content of the blood. This method does not recognize that the percentage oxygen saturation of arterial blood is also dependent upon the hæmoglobin level.

Fig. 2 shows the predicted relationship between mean systemic capillary oxygen tension and effective pulmonary flow for hæmoglobin values of $75,100,125,150,175$, and 200 per cent. With a normal hæmoglobin the relationship is approximately linear until the flow has been halved, and thereafter capillary oxygen tension falls with increased rapidity. The position of the other curves demonstrates that increased hæmoglobin produces a substantial gain in capillary oxygen tension when the flow is greatly reduced; thus, with a flow one-quarter of normal, successive equal increments of hæmoglobin from 100 to 125,150 , and 175 per cent will effect a gain in capillary oxygen tension of $7 \cdot 0,11.5$, and $14.75 \mathrm{~mm}$. $\mathrm{Hg}$ respectively. It is theoretically impossible for a patient to exist with a quarter normal effective pulmonary flow when the hæmoglobin is only 75 per cent.

The mean systemic capillary oxygen tension has been calculated in 63 of the patients from the observed percentage oxygen saturation of the arterial and mixed venous blood. Fig. 4 shows these values plotted against the effective pulmonary blood flow for each case with the predicted curve for a normal hæmoglobin superimposed. In 39 patients the effective pulmonary flow was less than half the average normal value and in all but one increased hæmoglobin had produced some gain in mean systemic capillary oxygen tension; this amounted to as much as $16 \mathrm{~mm}$. $\mathrm{Hg}$ in one case, and the mean value for the group was $8.3 \mathrm{~mm}$. above that predicted for a normal hæmoglobin. Several of the 24 patients whose effective pulmonary flow was greater than half normal were anæmic and in these capillary oxygen tension was $1.3 \mathrm{~mm}$. below that predicted for a normal hæmoglobin. For the whole series (63) the mean value for capillary oxygen tension was $4.6 \mathrm{~mm}$. $\mathrm{Hg}$ above that predicted for a normal hæmoglobin.

These observations lead to the conclusion that increased hæmoglobin plays an important part in maintaining tissue oxygen tension at rest when the effective pulmonary blood flow is reduced to less than half the average normal resting value by a central venous-arterial shunt.

\section{THE EXERCISE TOLERANCE}

Burchell et al. (1950) have shown in patients with central venous-arterial shunts that moderate exertion produces a significant reduction of the percentage oxygen saturation of the arterial and mixed venous blood, the extent of the fall during standard exercise varying. Similar observations 


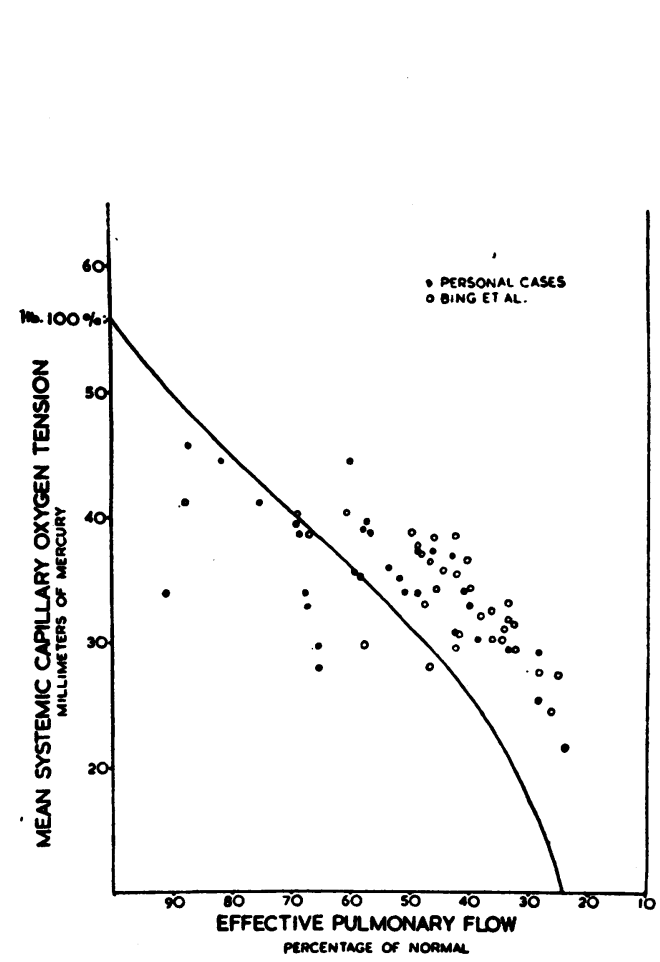

Fig. 4. - The relationship of the mean systemic capillary oxygen tension to the effective pulmonary flow.

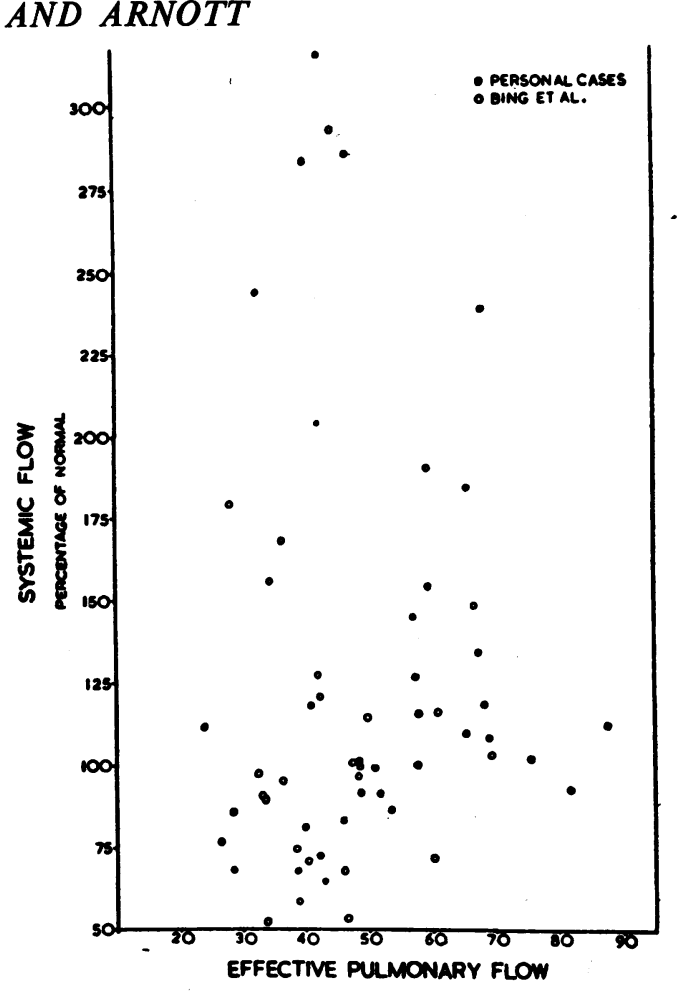

percentace of nomanal

FIG. 5.-The relationship of the systemic flow and the effective pulmonary flow.

have been made on five patients (four with Fallot's tetralogy and one with Eisenmenger's syndrome) who exercised upon a bicycle ergometer during cardiac catheterization; the findings are shown in Table III.

When the effective pulmonary blood flow fails to increase pari passu with the increased oxygen needed for sustained exercise the percentage oxygen saturation of the mixed venous blood must fall, and consequently, mean systemic capillary and tissue oxygen tensions fall.

Although a somewhat artificial procedure, the adaptive value of increased hæmoglobin can be expressed in terms of its capacity to increase oxygen absorption. This is done by determining the difference between the observed oxygen uptake during exercise and the calculated oxygen uptake on the assumption that the hæmoglobin level is normal while the effective pulmonary flow, the arterial and mixed venous oxygen saturations remain at the observed levels. For instance, in Case 15 (Table IV), whose oxygen uptake during exercise was $471 \mathrm{ml}$., Hb. 27.5 vol. per cent, arterial $\mathrm{O}_{2} 47.7$ per cent, mixed venous $\mathrm{O}_{2} 22.2$ per cent, and effective pulmonary blood flow $2.36 \mathrm{l}$./min., the oxygen uptake at a normal $\mathrm{Hb}$. of $20 \mathrm{vol}$. per cent is calculated by substituting values in formula 1 , and is found to be $344 \mathrm{ml} . / \mathrm{min}$. A gain of $127 \mathrm{ml} . / \mathrm{min}$. is therefore represented by the observed hæmoglobin content of $27.5 \mathrm{vol}$. per cent. When this difference is expressed as a percentage of the oxygen absorption calculated for a normal hæmoglobin the figure is of course identical to the observed percentage increase in the hæmoglobin. Therefore, in any given patient with central venous-arterial shunt, the maximum sustainable oxygen consumption (i.e. exercise tolerance) can be regarded as directly proportional to the hæmoglobin content of the blood.

It would appear possible that increased blood viscosity secondary to polycythæmia might modify these conclusions, but we have failed to confirm this in observations upon one patient (Case 18, Table IV). Cardiac catheterization was performed and his response to exercise upon the bicycle ergometer observed. Hæmoglobin was then reduced from 161 to 143 per cent by frequent small 
TABLE III

The Effect of Exercise in Five Patients

\begin{tabular}{|c|c|c|c|c|c|c|c|c|c|}
\hline \multirow{2}{*}{$\begin{array}{l}\text { Case } \\
\text { No. }\end{array}$} & \multirow{2}{*}{ Condition } & \multirow{2}{*}{$\begin{array}{c}\text { Oxygen } \\
\text { capacity } \\
\text { (blood } \\
\text { vol. \%) }\end{array}$} & \multirow{2}{*}{ State } & \multirow{2}{*}{$\begin{array}{l}\text { Oxygen } \\
\text { consump- } \\
\text { tion } \\
\text { (ml./min.) }\end{array}$} & \multicolumn{2}{|c|}{$\begin{array}{c}\text { Percentage saturation } \\
\text { of blood }\end{array}$} & \multicolumn{2}{|c|}{$\begin{array}{l}\text { Blood flow } \\
\text { (litres/min.) }\end{array}$} & \multirow{2}{*}{$\begin{array}{c}\text { V-A } \\
\text { shunt } \\
\text { (per } \\
\text { centage of } \\
\text { systemic } \\
\text { flow) }\end{array}$} \\
\hline & & & & & Arterial & $\begin{array}{l}\text { Mixed } \\
\text { venous }\end{array}$ & Systemic & $\begin{array}{c}\text { Effec. } \\
\text { pulmonary }\end{array}$ & \\
\hline 15 & Fallot & 27.5 & & 176 & 65 & 57 & $8 \cdot 1$ & $1 \cdot 7$ & 79 \\
\hline 16 & Follot & & & & & & & $2 \cdot 4$ & \\
\hline 16 & Fallot & $24 \cdot 5$ & $\begin{array}{l}\text { Rest } \\
\text { Exercise }\end{array}$ & $\begin{array}{l}220 \\
675\end{array}$ & $\begin{array}{l}81 \\
64\end{array}$ & $\begin{array}{l}53 \\
32\end{array}$ & $\begin{array}{l}3.2 \\
8.5\end{array}$ & $\begin{array}{l}2 \cdot 1 \\
4 \cdot 3\end{array}$ & $\begin{array}{l}30 \\
49\end{array}$ \\
\hline 17 & Fallot & $29 \cdot 3$ & Rest. & 237 & 79 & 69 & 7.8 & $3 \cdot 1$ & 61 \\
\hline 24 & E. comp. & 27.2 & $\begin{array}{l}\text { Exercise } \\
\text { Rest }\end{array}$ & 897 & $\begin{array}{l}49 \\
88\end{array}$ & 34 & $\begin{array}{r}21 \cdot 2 \\
2.8\end{array}$ & $\begin{array}{l}5.0 \\
2.2\end{array}$ & $\begin{array}{l}76 \\
21\end{array}$ \\
\hline & & 21.2 & Exercise & 592 & $\begin{array}{l}00 \\
68\end{array}$ & 26 & $\begin{array}{l}2 \cdot 8 \\
5 \cdot 3\end{array}$ & $\begin{array}{l}2 \cdot 2 \\
3 \cdot 2\end{array}$ & $\begin{array}{l}21 \\
40\end{array}$ \\
\hline 18 & Fallot & $32 \cdot 3$ & Rest & 285 & 82 & 68 & $6 \cdot 1$ & $3 \cdot 3$ & 45 \\
\hline \multirow{2}{*}{\multicolumn{2}{|c|}{$\begin{array}{l}\text { Ditto after vene- } \\
\text { section }\end{array}$}} & $28 \cdot 7$ & $\begin{array}{l}\text { Exercise } \\
\text { Rest }\end{array}$ & $\begin{array}{l}980 \\
254\end{array}$ & $\begin{array}{l}73 \\
78\end{array}$ & $\begin{array}{l}42 \\
63\end{array}$ & $\begin{array}{l}9.9 \\
6.0\end{array}$ & $\begin{array}{l}5.9 \\
2.8\end{array}$ & $\begin{array}{l}41 \\
53\end{array}$ \\
\hline & & & Exercise & 740 & 58 & 35 & 10.8 & $4 \cdot 3$ & 60 \\
\hline
\end{tabular}

TABLE IV

Data on Arterial Blood Composition, Ventilation Equivalent, and Ventilation Ratio

\begin{tabular}{|c|c|c|c|c|c|c|}
\hline (1). & (2) & (3) & (4) & (5) & (6) & (7) \\
\hline \multirow{2}{*}{$\begin{array}{l}\text { Case } \\
\text { No. }\end{array}$} & \multicolumn{3}{|c|}{ Arterial blood } & \multirow{2}{*}{$\begin{array}{c}\text { Oxygen } \\
\text { ventilation } \\
\text { equivalent } \\
\text { (VE) } \\
\text { (normal=2.78) }\end{array}$} & \multirow{2}{*}{$\begin{array}{c}\begin{array}{c}\text { Ventilation } \\
\text { ratio } \\
\text { (VR) } \\
\text { VR }=\text { VE/2.78 }\end{array} \\
\end{array}$} & \multirow{2}{*}{$\begin{array}{c}\text { Calculated } \\
\text { arterial } \\
\boldsymbol{p H}\end{array}$} \\
\hline & $\begin{array}{c}\mathrm{O}_{2} \text { capacity } \\
\text { (vols. \%) }\end{array}$ & $\begin{array}{l}\text { Per cent } \\
\text { saturation }\end{array}$ & $\begin{array}{c}\text { Total } \\
\mathrm{CO}_{2} \text { (vols. \%) }\end{array}$ & & & \\
\hline $\begin{array}{c}8 \\
2(1) \\
2(2) \\
4(1) \\
4(2) \\
36(1) \\
36(2) \\
7(3) \\
18(1) \\
18(2) \\
3 \\
35 \\
10 \\
16 \\
17 \\
5 \\
6 \\
24 \\
19 \\
21 \\
20 \\
25 \\
30 \\
32\end{array}$ & 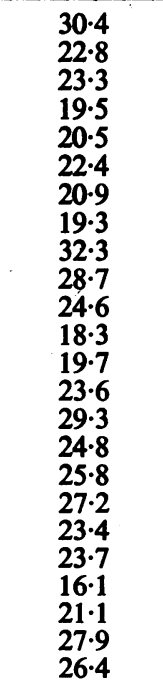 & $\begin{array}{l}81 \cdot 0 \\
81 \cdot 3 \\
77 \cdot 0 \\
71 \cdot 6 \\
88 \cdot 3 \\
79 \cdot 4 \\
86 \cdot 0 \\
76 \cdot 4 \\
82 \cdot 5 \\
78 \cdot 8 \\
75 \cdot 9 \\
78 \cdot 4 \\
87 \cdot 3 \\
81 \cdot 0 \\
79 \cdot 1 \\
79 \cdot 3 \\
76 \cdot 3 \\
87 \cdot 7 \\
79 \cdot 3 \\
74 \cdot 6 \\
75 \cdot 1 \\
89 \cdot 8 \\
75 \cdot 2 \\
83 \cdot 8\end{array}$ & $\begin{array}{l}30.4 \\
40.9 \\
42 \cdot 3 \\
40.8 \\
40 \cdot 2 \\
38.7 \\
44 \cdot 2 \\
41.8 \\
33.0 \\
33.7 \\
40.7 \\
53 \cdot 2 \\
43.9 \\
38 \cdot 2 \\
37 \cdot 1 \\
42 \cdot 3 \\
36.8 \\
38 \cdot 3 \\
39 \cdot 3 \\
36.0 \\
46.2 \\
43.7 \\
36.9 \\
40.8\end{array}$ & 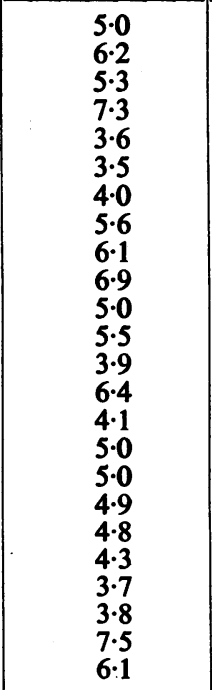 & $\begin{array}{l}1.8 \\
2.2 \\
1.9 \\
2.6 \\
1.3 \\
1.3 \\
1.5 \\
2.0 \\
2.2 \\
2.5 \\
1.8 \\
2.0 \\
1.4 \\
2.3 \\
1.5 \\
1.8 \\
1.8 \\
1.8 \\
1.7 \\
1.6 \\
1.3 \\
1.4 \\
2.7 \\
2.2\end{array}$ & $\begin{array}{l}7 \cdot 31 \\
7 \cdot 35 \\
7 \cdot 39 \\
7 \cdot 40 \\
7 \cdot 38 \\
7 \cdot 38 \\
7 \cdot 37 \\
7 \cdot 40 \\
7 \cdot 30 \\
7 \cdot 31 \\
7 \cdot 39 \\
7 \cdot 45 \\
7 \cdot 36 \\
7 \cdot 34 \\
7 \cdot 37 \\
7 \cdot 37 \\
7 \cdot 37 \\
7 \cdot 33 \\
7 \cdot 37 \\
7 \cdot 37 \\
7 \cdot 44 \\
7 \cdot 36 \\
7 \cdot 35 \\
7 \cdot 35\end{array}$ \\
\hline $\begin{array}{l}\text { Mean } \\
\text { S.D. }\end{array}$ & $\begin{array}{r}23.9 \\
\pm 4.0\end{array}$ & & & $\begin{array}{r}5.1 \\
\pm 1.2\end{array}$ & $\begin{array}{r}1.9 \\
\pm 0.4\end{array}$ & $\begin{array}{r}7.37 \\
\pm 0.04\end{array}$ \\
\hline
\end{tabular}


venesections; this produced a slight deterioration in his exercise tolerance. Cardiac catheterization was then repeated and demonstrated a significant reduction of the resting arterial and mixed venous oxygen saturations with an increase in the absolute and relative size of the central venous-arterial shunt. His response to the same exercise was again studied; and although he failed to achieve the oxygen uptake observed during the first investigation, the arterial and mixed venous saturations showed greater depression, and the shunt was larger.

\section{Adaptive Value of Increased Cardiac OutPut}

In patients with central venous-arterial shunts the measurements of cardiac output by application of the direct Fick principle presents recognized difficulties. A large collateral circulation to the lungs and left-to-right intracardiac shunts render the effective pulmonary and systemic blood flows erroneously low estimates of the total pulmonary blood flow and left ventricular output respectively. Collateral pulmonary blood flow cannot be measured and therefore an approximate estimate of the size of left-to-right intracardiac shunts-although frequently attempted-is of little value. For this reason variation in the size of the cardiac output as an adaptation to the central venous-arterial shunt can only be considered in relation to the volume of the systemic blood flow.

In the patients observed personally the mean value for the resting systemic arterio-venous oxygen difference $(4 \cdot 34 \pm 0.24$ vols per $100 \mathrm{ml}$.); approximated closely to the predicted mean value for normal subjècts in the supine position, and only in patients with pulmonary arterio-venous aneurysms was this consistently reduced $(3.39 \pm 0.35$ vols. per $100 \mathrm{ml}$.); therefore an increased systemic blood flow is not a constant accompaniment of central venous-arterial shunt.

The relationship between systemic and effective pulmonary blood flows-calculated from the respective arterio-venous oxygen differences and expressed as percentage of the average normal value-is shown in Fig. 5. Compensatory increase in the systemic blood flow would be shown by a negative correlation between these two values, but none exists. To evaluate the gain from increased resting systemic blood flow it would be necessary to know what effect, if any, this would have upon the volume of the effective pulmonary flow. There is no evidence that an increase of the former produces a proportionate increase of the latter. On the contrary, studies by Hamilton et al. (1950) and personal observations upon Cases 6 and 14 suggest that adequate blood flow into the pulmonary artery through a stenosed infundibulum or pulmonary valve is maintained by a high pressure-gradient between the right ventricle and pulmonary artery during systole. When a free communication exists between the two ventricles (as in Fallot's tetralogy) the contents of the right ventricle will be ejected into pulmonary and systemic vascular beds in a proportion that will be determined by the relative resistance offered by each system. A normal systemic peripheral resistance is obligatory if effective pulmonary flow is to be maintained, and relaxation of systemic arteriolar tone will serve only to reduce the pulmonary arterial blood flow in these cases, although it may be accompanied by an increased systemic flow.

The systemic blood flow is the sum of two components: (1) the effective pulmonary blood flow, and (2) the central venous-arterial shunt; therefore, it may be restricted by purely mechanical means if pulmonary stenosis is associated with a septal defect that limits the size of the central venous-arterial shunt. This fact probably accounts for the very low resting systemic blood flow occasionally observed in patients diagnosed as suffering from Fallot's tetralogy and suggests that the aorta does not, in fact, over-ride the ventricular septal defect. The advantage or otherwise of a restricted venous-arterial shunt is difficult to assess because functional capacity depends primarily upon the volume of the effective pulmonary blood flow.

The effect of exercise upon the volume of the systemic and effective pulmonary blood flows has been studied in five patients (Table III). The effective pulmonary flow was increased in all cases; the systemic flow increased in four and fell slightly in one (Case 15; this anomalous finding may have been due to the abnormally high resting flow observed). The contribution of the central 
venous-arterial shunt to the volume of the systemic blood flow rose in three and fell in two; in one (Case 18) the response was reversed following moderate venesection.

It has been concluded from these observations that the volume of the systemic blood flow in this group of patients is largely governed by the nature and severity of the cardiac abnormality, and that it cannot, therefore, make any adaptive contribution.

In patients with congenital pulmonary arterio-venous aneurysms the venous blood passes readily into the pulmonary arterial tree and the mean pulmonary arterial pressure is usually normal or sub-normal. The resistance of the normal pulmonary capillary bed is low and will not rise until blood flow is greatly increased, therefore we might expect the relative proportion of venous blood entering the abnormal channels to be little changed by an increase in flow. The ease with which these patients can increase their effective pulmonary blood flow probably accounts for the good exercise tolerance that is usually observed, but there is no evidence to suggest that increased systemic flow is an important adaptive mechanism at rest-in four patients investigated the mean increase of resting systemic flow was approximately 30 per cent above the average normal value.

\section{RESPIRATORY FUNCTION}

Hyperpncea at Rest. Table IV presents data on resting ventilation and arterial blood composition from 20 patients with veno-arterial shunt. Four of the patients were re-investigated later when time or treatment had materially altered their clinical status. Thus the table lists 24 sets of observations on 20 patients; showing in Col. 2-4 the results of arterial blood analysis, and in Col. 5-6 the corresponding figures for oxygen ventilation equivalent (VE) and for the ventilatory ratio (VR) derived therefrom. No data has been included from patients in whom the respiratory quotient at rest lay outside the normal limits of 0.7-1.0. The only other exclusions were in cases where the ventilation and the arterial blood data were insufficiently contemporary.

Hyperpnœa-which seems to be the sole abnormality of respiratory function in these patients at restcould not be assessed in terms of absolute ventilation rates per unit surface area in view of the age-composition of the series. Normal standards exist for adults (Matheson and Gray, 1950; Baldwin et al., 1949), and for males from 11-18 years (Morse et. al., 1949), but not for younger boys or for girls. Instead, therefore, the ventilation equivalent for oxygen (VE) has been employed, since this relates ventilation to oxygen consumption, and therefore is less affected by differences in age and sex. It corresponds to the amount of ventilation (litres, B.T.P.S.) required for an oxygen uptake of $100 \mathrm{ml}$. (dry, N.T.P.).

The ventilatory ratio (VR) figures (Col. 6, Table IV) are included as required by a later context. The VR represents a useful common notation for different types of ventilatory measurement: it is the ratio any such measurement bears to the appropriate normal standard. The observations of Matheson and Gray (1950) on 100 normal male students provide the normal standard for oxygen ventilation equivalent, their mean value being $2 \cdot 78 \pm 0 \cdot 45$. The VR values of Col. 6 are derived thus: Observed VE/2.78.

Taking twice the standard deviation above the mean as the upper limit of normality, this becomes 3.68 or 1.34 in terms of VR. Only two of the 24 listed observations lie marginally below this limit-both incidentally, from Fallot patients after successful Blalock operations. Thus the very high incidence of hyperpnœa at rest reported by Bing et al. (1948) is confirmed in the present series.

As regards the degree of hyperpnœa, comparison with their data is impracticable. Although in their series very high ventilation rates were frequent, in more than half of the records the RQ value at rest was greater than unity, thus making it plain that over-ventilation was at least accessory to hyperpnœa in producing the high ventilation rates observed. The exclusion of such observations from the present series does not guarantee that no over-ventilation occurred, but ensures that the ventilation-ratios recorded cannot have been seriously exaggerated thereby.

Pathogenesis of Resting Hyperpncea. Bing et al. (1949) attributed the hyperpnœa to the prevailing anoxæmia and noted that, since the origin of the latter was extra-pulmonary the hyperpnœic response could have no adaptive value. However, the simple cause and effect relationship postulated is difficult to accept; for the correlation between anoxæmia and hyperpnœa is slight in their data as in our own.

This suggests two possibilities; either that individuals vary surprisingly in their capacity to respond to anoxæmia or that the ventilatory demands thus set up are subject to modification by other influences, themselves independent of the degree of anoxæmia. The latter concept corresponds in essentials with that 
of Gray's multiple factor theory $(1946,1950)$ which visualizes the ventilation ratio during anoxæmia as depending not on the anoxic stimulus alone, but also on the degree to which this is reinforced or inhibited by the levels of arterial $p \mathrm{H}$ and $p \mathrm{CO}_{2}$ then prevailing.

Gray's "chemical ventilation equation" (which cannot be reproduced in the space available) defines the quantitative relations between ventilation ratio (VR) and arterial $p \mathrm{O}_{2}, p \mathrm{CO}_{2}$, and $p \mathrm{H}$ in normal subjects at rest, over a wide range of induced changes in the latter factors, including all degrees of anoxia compatible with normal neural function. The equation would be a fallible touchstone for the recognition of aberrations of respiratory control in cases of anoxæmia generally, since these mostly lack the normal ventilatory capacity presupposed by the formula. Patients with a veno-arterial shunt, however, are not defective in this respect and failure of the equation to hold good in them might reasonably indicate disturbed central respiratory control.

The data in Col. 2-6, Table IV, was accordingly reviewed with this in mind. Only the briefest outline can be given of the treatment to which it was subjected. Since arterial $p H$ values were not known, it was impossible to settle the question by the direct comparison of observed VR with VR as predicted by the equation. Instead, for each set of data the equation was solved for $p \mathrm{H}$, using the observed $\mathrm{VR}$ as a known term: in other words the theoretical $p \mathrm{H}$ level was calculated that would give to the sum of the three humoral stimuli the value of the observed VR.

Col. 7 lists the calculated $p \mathrm{H}$ values. All are within the range $7 \cdot 30-7 \cdot 45$, which agrees with the range of values determined in their cases by Bing et al. (1949). The table exhibits obvious negative correlation between $\mathrm{O}_{2}$ capacity and calculated $p \mathrm{H}$, which is significant in the statistical sense $(\mathrm{r}=-0.841$, i.e. over 4

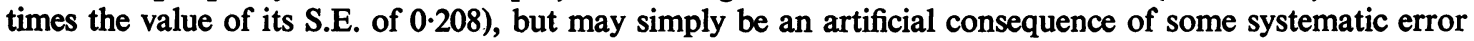
in the calculations linked to $\mathrm{O}_{2}$ capacity. But the regression equation

$$
p \mathrm{H}=-0.0074\left(\mathrm{O}_{2} \text { capacity }-23 \cdot 87\right)+7 \cdot 37
$$

gives for blood of normal $\mathrm{O}_{2}$ capacity $(20$ vols. $\%$ a $p \mathrm{H}$ of $7 \cdot 40$, i.e. the accepted mean normal value.

A better idea of the significance of this result can be given by saying that, for the mean of the calculated $p \mathrm{H}$ figures (corrected for $\mathrm{O}_{2}$ capacity) to be lessened from $7 \cdot 40$ to $7 \cdot 35$ would have required, on the average, thrice the degree of hyperpnœa actually observed: and for its displacement to $7 \cdot 45$, the average ventilation would have had to be slightly subnormal.

These results therefore support the assumption that the level of ventilation in these cases is determined by the normal humoral stimuli, operating at levels conditioned by the circulatory defect. There is no need to invoke any hypothetical alteration of sensitivity of the respiratory centre.

\section{RESPIRATORY RESPONSE TO EXERCISE}

Patients with a veno-arterial shunt exhibit, in their ventilatory response to exercise, a fundamental abnormality that seems to have escaped comment, although it is as frequent, and in its way as striking as the resting hyperpnœa which has been thoroughly discussed. Part of that discussion, as has been noted, concerned the difficulty in justifying the resting hyperpnœa in terms of useful effect; which makes more curious the failure to remark how frequently the ventilatory response to exercise is defective; for it is in this deficiency's existence that the most obvious justification for the resting hyperpnœa is found. The defect amounts to a retardation-often very considerable - of the normal increase in ventilation upon starting exercise, so that during the first three or four minutes of steady exercise ventilation lags abnormally behind metabolic needs, and only reaches a final plateau after an interval much longer than in normal subjects.

Most of the evidence to be presented on this point is in the results of the standard one-minute, thirty-step exercise of Baldwin et al. (1949), which was used throughout the series. When interest was aroused in the nature of the defective ventilatory response, a more informative procedure was adopted, and this will be described first, although only four of the later patients were subjected to it.

Sustained Exercise. Three normal subjects and four of the Fallot patients carried out (after earlier practice), in the supine position, exercise on the bicycle ergometer, sustained at a uniform 


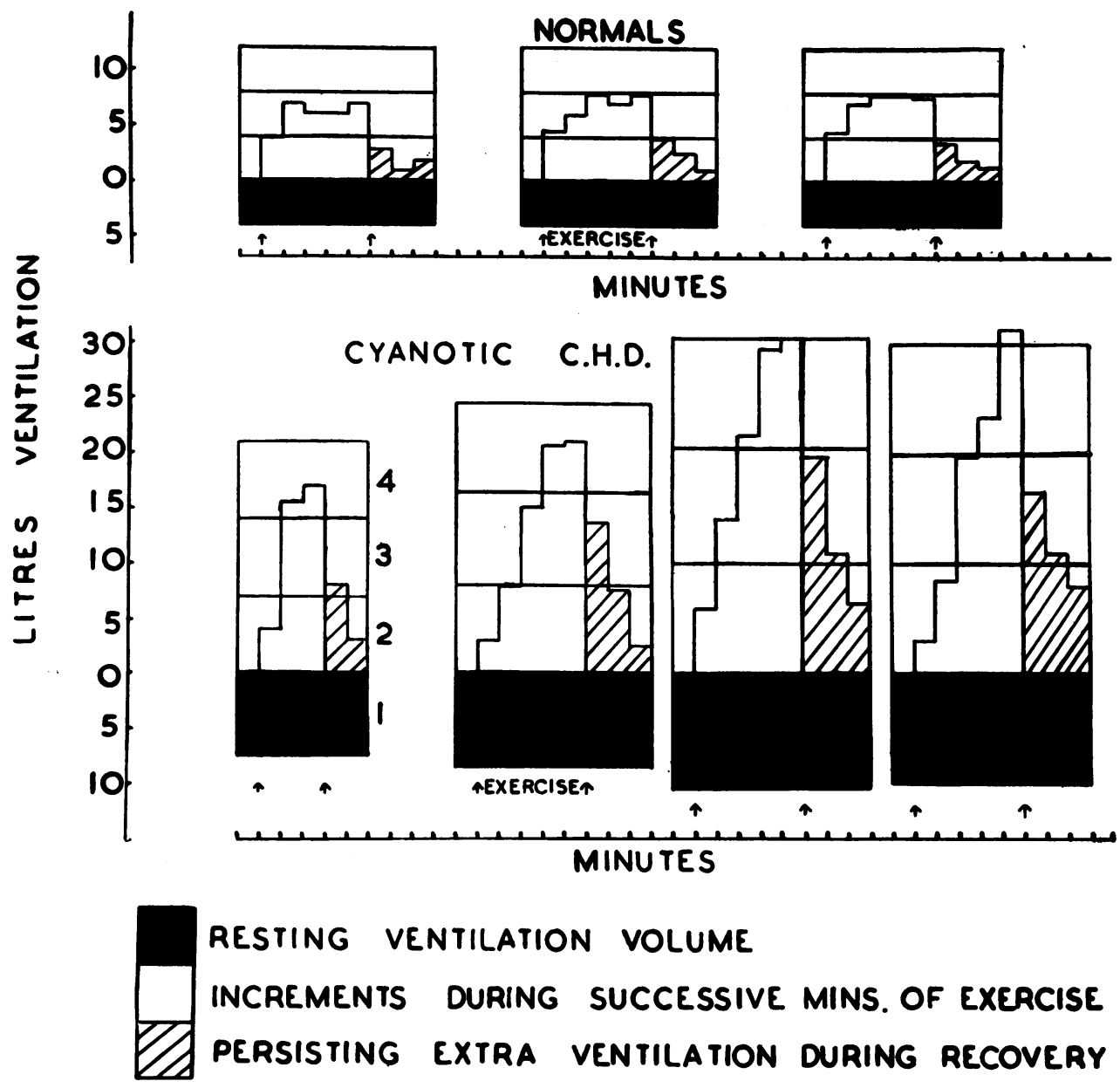

Fig. 6.-The increase of ventilation during and after exercise in normals and cyanotic congenital heart disease.

rate for five minutes and of intensity corresponding to an oxygen uptake per square metre of from 500 to $600 \mathrm{ml}$. a minute. The procedure has been described, the only difference here being the omission of all sample-taking to preserve continuity of the ventilatory record. The Tissot tracing was uninterrupted through rest, the five minutes for which exercise had to be sustained for the Fallot patients to achieve steady levels of ventilation, and two or three minutes of recovery.

Fig. 6 illustrates the results, showing for the seven subjects block diagrams of the actual ventilation per square metre in each successive minute; with resting ventilation below the line in black, and above it the increases attributable to the exercise; unshaded, during the exercise; and hatched, during recovery. The difference between the responses in controls and in patients is too apparent to require detailed comment. Each normal had achieved 95 per cent of his augmentation of ventilation within ninety seconds of beginning work, whereas none of the patients was comparably near equilibrium even after twice that period. The maximum separation of the groups occurs, however, in the first minute of work when the controls' response exceeds that of the patients most conspicuously as regards the ratio exercise:resting ventilation, but also in the absolute volume of extra ventilation. 
This lag of ventilation response must certainly have caused considerable retention of carbon dioxide in the early minutes; and it is obvious that oxygen uptake from the lungs would also have been greatly impaired had not the patients carried over into exercise, as a legacy from their resting hyperpnœa, abnormally high alveolar oxygen tensions. Consequently, abnormally great reductions in these tensions could occur without serious unsaturation developing in the pulmonary venous blood. This effect of the hyperpnœa at rest must constitute a useful protection; for although these patients do eventually stabilize their ventilation-presumably at the level of requirement-the process occupies nearly five minutes during very mild exercise; and without the preexisting "store" of oxygen in the lungs even this level of exertion would have been difficult to sutain for that time.

Standard One-minute Step Exercise. The results of the standard 30-step exercise are listed in Table V. Its one-minute duration, and the easy nature of the exercise make this a test which nearly every ambulant patient can accomplish; but its brevity means that what is being tested is not respiratory performance under working conditions so much as the efficiency and speed of cardiorespiratory response during the transition from the resting state. Even healthy subjects hardly reach their new equilibrium within the minute period and the slight fall in R.Q. which is normally

TABLE V

Relation of Anoxic Partial Ventilatory Stimulus (VRO 2 ) and Speed of Ventilatory Response to Exercise (30-STEP TEST)

\begin{tabular}{|c|c|c|c|c|c|c|}
\hline (1) & (2) & (3) & (4) & (5) & (6) & (7) \\
\hline \multirow{2}{*}{$\begin{array}{l}\text { Case } \\
\text { No. }\end{array}$} & \multirow{2}{*}{$\begin{array}{l}\text { Resting } \\
\text { arterial } \\
\mathrm{pO}_{2} \\
(\mathrm{~mm} . \mathrm{Hg})\end{array}$} & \multirow{2}{*}{$\begin{array}{c}\text { Corresponding } \\
\mathrm{VRO}_{2} \times 4.02 \\
\text { (litres } / \mathrm{M}^{2} / \mathrm{min} \text {.) }\end{array}$} & \multicolumn{3}{|c|}{ Ratio exercise: resting } & \multirow{2}{*}{$\begin{array}{l}\text { Ventilation } \\
\text { increment in } \\
\text { one minute } \\
\text { exercise } \\
\text { (litres/ } \mathbf{M}^{2} \text { ) }\end{array}$} \\
\hline & & & $\begin{array}{c}\mathrm{O}_{2} \\
\text { uptake }\end{array}$ & $\underset{\text { output }}{\mathrm{CO}_{2}}$ & Ventilation & \\
\hline $\begin{array}{c}4(1) \\
21 \\
20 \\
30 \\
3 \\
7(2) \\
6 \\
2(2) \\
35 \\
7(1) \\
19 \\
5 \\
36(1) \\
2(1) \\
32 \\
36(2) \\
4(2) \\
25\end{array}$ & $\begin{array}{l}38 \cdot 4 \\
40.5 \\
40.9 \\
41 \cdot 1 \\
41 \cdot 8 \\
42 \cdot 3 \\
42 \cdot 3 \\
42 \cdot 7 \\
44.0 \\
45 \cdot 1 \\
45 \cdot 1 \\
45 \cdot 2 \\
45 \cdot 3 \\
47 \cdot 8 \\
50.0 \\
53.0 \\
57 \cdot 7 \\
58 \cdot 5\end{array}$ & $\begin{array}{r}15.2 \\
12.9 \\
12.5 \\
12.3 \\
11.7 \\
11.2 \\
11.2 \\
10.9 \\
9.8 \\
9.0 \\
9.0 \\
8.9 \\
8.8 \\
7.1 \\
5.9 \\
4.4 \\
2.8 \\
2.6\end{array}$ & $\begin{array}{l}1.9 \\
1.9 \\
1.8 \\
1.7 \\
2.1 \\
2.1 \\
1.9 \\
2.3 \\
2.5 \\
2.4 \\
1.9 \\
2.3 \\
2.4 \\
2.1 \\
2.7 \\
2.4 \\
3.4 \\
3.3\end{array}$ & $\begin{array}{l}1.6 \\
1.6 \\
1.8 \\
1.8 \\
1.7 \\
1.8 \\
2.1 \\
2.1 \\
2.1 \\
2.3 \\
1.9 \\
2.4 \\
2.3 \\
2.7 \\
2.6 \\
2.9 \\
3.4 \\
3.4\end{array}$ & $\begin{array}{l}1.5 \\
1.5 \\
1.9 \\
1.7 \\
2.1 \\
1.8 \\
1.7 \\
1.7 \\
2.2 \\
1.7 \\
2.0 \\
2.3 \\
2.4 \\
2.7 \\
2.1 \\
3.3 \\
3.3 \\
3.3\end{array}$ & $\begin{array}{r}4.9 \\
3.1 \\
4 \cdot 2 \\
8.5 \\
7.9 \\
6.5 \\
5.0 \\
5.6 \\
7.4 \\
7.5 \\
7.0 \\
8.2 \\
8.9 \\
15.2 \\
10.6 \\
13.8 \\
12.4 \\
13.4\end{array}$ \\
\hline $\begin{array}{l}\text { Mean } \\
\pm \\
\text { s.D. }\end{array}$ & $\begin{array}{r}45 \cdot 7 \\
\pm 5 \cdot 8\end{array}$ & $\begin{array}{r}9 \cdot 2 \\
\pm 3 \cdot 4\end{array}$ & $\begin{array}{r}2.3 \\
\pm 0.4\end{array}$ & $\begin{array}{r}2.2 \\
\pm 0.5\end{array}$ & $\begin{array}{r}2.2 \\
\pm 0.6\end{array}$ & $\begin{array}{r}8.4 \\
\pm 3.4\end{array}$ \\
\hline $\begin{array}{l}\text { Coefficient of } \\
\text { correlation (r) } \\
\text { with } \\
\left(\mathrm{VRO}_{2} \times 4.02\right)\end{array}$ & 一 & 一 & -0.83 & -0.89 & -0.90 & -0.85 \\
\hline
\end{tabular}

Arterial $\mathrm{pO}_{2}$ figures (Col. 2) are for assumed $p \mathrm{H}$ of $7 \cdot 40$. In col. $3\left(4.02 \times \mathrm{VRO}_{2}\right)$ the ventilatory stimulation (as litres/M2/min.) corresponding to each $\mathrm{pO}_{2}$ figure is shown. Cols. 4,5 , and 6 show exercise: resting ratios of gas exchange and ventilation. Col. 7 lists actual increments (over resting levels) of ventilation during the test. 
seen indicates that the ventilatory response lags behind the increase in lung blood flow. In all six age and sex groups in Baldwin et al.'s (1949) series of normals, ventilation was higher in the first minute after the exercise than during the minute of its performance. Taking their young adult male and female groups together, the mean responses were as follows: (1) ratio exercise: resting ventilation $=3.13$; (2) ratio exercise: resting $\mathrm{O}_{2}$ uptake $=3.56$; and (3) actual increase in ventilation $=6.6$ (litres/ $/ \mathrm{M}^{2}$ ). They give no details of $\mathrm{CO}_{2}$ output, but it is normal for the R.Q. to fall during the exercise, therefore the exercise: resting $\mathrm{CO}_{2}$ output ratio should be intermediate between ratios 1 and 2 .

Properly carried out (as it was by all these patients) the exercise involves an amount of work that is a direct function of body weight or, practically speaking, of surface area: therefore its cost in extra gas exchange per unit surface area ought to be fairly constant; and if from inadequacy of either the ventilatory or the circulatory responses figures of the order quoted above are not achieved, it is likely that, by the end of the exercise, the degree of $\mathrm{CO}_{2}$ retention, and probably also of oxygen debt, will be abnormally high.

Results. Table V includes data on the results of the standard step exercise (18 observations on 14 patients; the double data again being from patients whose clinical state had undergone material change between the tests). In contrast to the case of the resting hyperpnca, there seemed, in the results of the exercise test, to be a rough parallelism between the clinical disability and the defect of ventilatory response to exercise. Moreover, when the latter was plotted against resting arterial oxygen tension (assuming $p \mathrm{H}$ of 7.40) a non-linear relationship was suggested with the smallest responses to exercise occurring with the lowest arterial oxygen tensions at rest (Col. 2). A much clearer relationship emerged when the oxygen tensions were translated into the corresponding anoxic stimulus $\left(\mathrm{VRO}_{2}\right)$ by Gray's formula:

$$
\mathrm{VRO}_{2}=2 \cdot 118 \times 10^{-8}\left(104-\mathrm{pO}_{2}\right)^{4 \cdot 9}
$$

or alternatively (as in Col. 3 ) into terms of the ventilatory volume equivalent to such anoxic stimulus, by multiplying the above expression by 4.02. (The latter figure was taken from Matheson and Gray's (1950) paper already quoted, as representing normal ventilation volume per square metre or unit VR.)

Table V shows the values of the coefficients of correlation between each set of exercise-responses and the corresponding value of $\left(4 \cdot 02 \mathrm{VRO}_{2}\right)$ in Col. 3. All correlations were negative and more than three times their standard error of 0.242 .

Significance of Defective Response. The presence of a veno-arterial shunt might logically be expected rather to enhance than to impair the ventilatory response to exertion; for exertion at once increases the volume of blood shunted to the arterial side, both absolutely and in relation to the total flow, and this effect is greatest in those with conditions (such as pulmonary stenosis or high pulmonary resistance) that commonly produce the lowest arterial saturation at rest. This should result in the early arrival at the respiratory centre and chemo-receptors of much additional humoral stimulation, so that a greater and more immediate ventilatory increase might be expected.

The reason why logical expectation should thus be reversed in the event must for proof await further investigation. But there is one speculative explanation that is hard to resist. Anoxia is known to be a respiratory stimulus only within certain limits, beyond which depression overtakes or succeeds stimulation. The precise level at which this occurs is variable, but Gray puts it at about $30 \mathrm{~mm} . \mathrm{Hg}$ arterial $p \mathrm{O}_{2}$, and specifically limits the application of his equation to the range above this. This tension (at a $p \mathrm{H}$ of 7.40) would correspond to 59 to 60 per cent arterial saturation. No patient listed in Table $\mathrm{V}$ had a resting arterial saturation below 70 per cent, but the enlargement of the shunt on exertion must in many have depressed arterial saturation below the critical level before the end of the test-after periods probably determined largely by the arterial saturations before work began.

In thus thinking of a "critical level" of anoxia, it is possible to visualize it either as one at which the ventilatory stimulus has its maximal effect, or, alternatively, as the level at which the effects of still-increasing peripheral chemo-receptor stimulation may be overtaken by those of central depression. In either possibility, the concept illustrated in Fig. 7 is appropriate.

In this figure, similar distances along ordinate or abscissa represent similar ventilation volumes-on 
the former the increases (litres $/ \mathrm{M}^{2} / \mathrm{min}$.) observed during the standard exercise, and on the latter the ventilation (litres $/ \mathrm{M}^{2} / \mathrm{min}$.) that would result from the anoxic stimulus $\left(\mathrm{VRO}_{2}\right)$ existing at rest if it were unopposed by the other partial factors. The three scales provided on the abscissa represent, in downward order: (1) resting arterial $\mathrm{pO}_{2}$; (2) equivalent $\mathrm{VRO}_{2}$; and (3) corresponding ventilatory volume. The main purpose of Fig. 7, however, is to illustrate the degree of further anoxic stimulation possible at any level of resting $\mathrm{pO}_{2}$ before anoxia ceases to stimulate or even becomes depressant to the respiratory centre. To

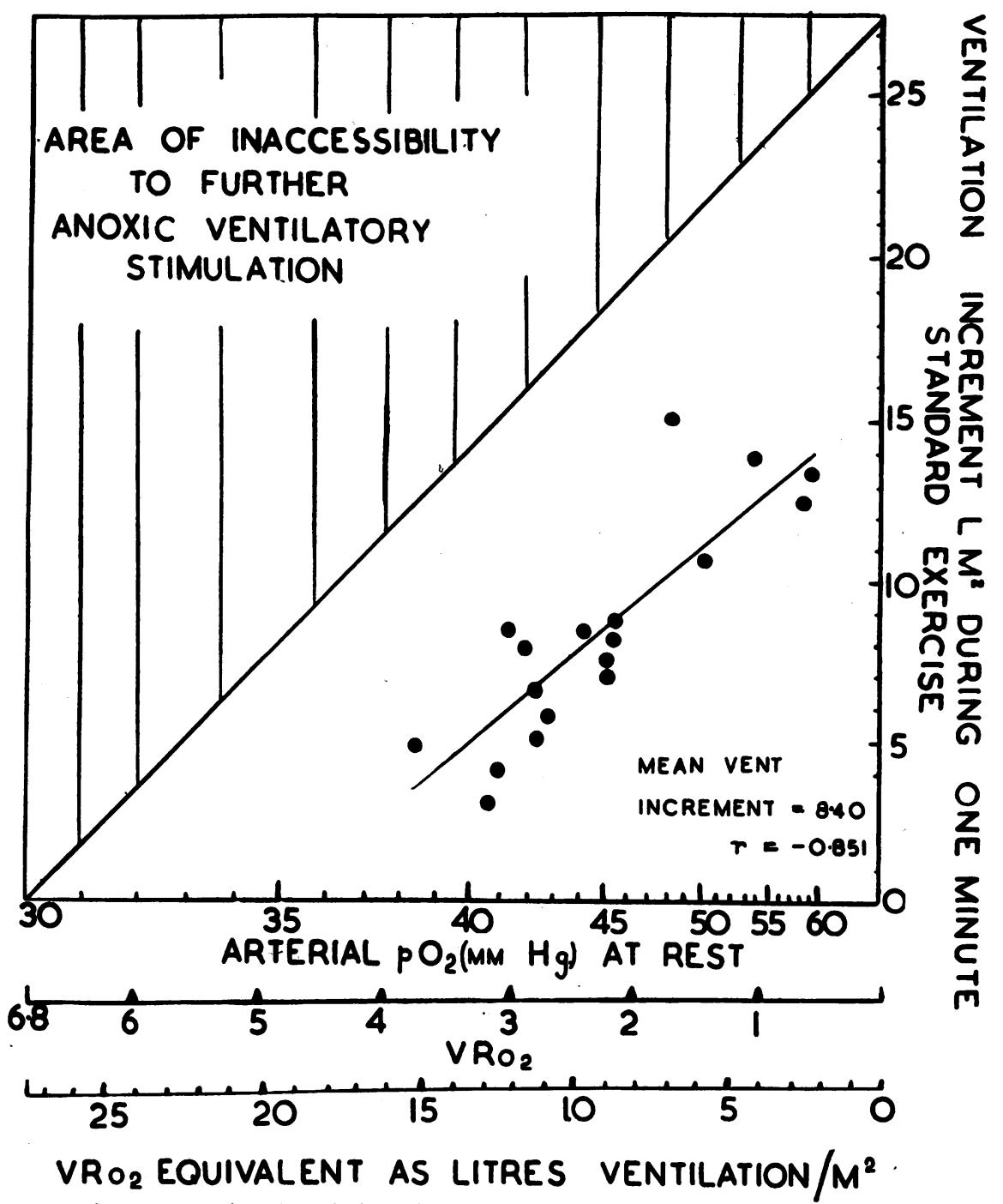

Fig. 7.-Diagram showing the relationship of the increase of ventilation during standard exercise and the arterial $\mathrm{pO}_{2}$ at rest.

this end, the ordinate has been given a finite length equal to that of the abscissa (which covers the whole range of possible anoxic stimulus-intensity). The square thus formed is divided by a diagonal. The vertical interval between this diagonal and the point on the abscissa corresponding to any resting arterial oxygen tension, represents the effective remaining capacity for ventilatory response to an increase in anoxia, in terms of the volume of additional ventilation such stimulus should evoke. If two patients are imagined with arterial tensions of 35 and $55 \mathrm{~mm}$. Hg respectively, although their actual resting rates of ventilation might well be identical, yet-it can be seen from the diagram - the maximum ventilatory response to further anoxia which could be expected from one would be 8 litres, but from the other 24, before the point of commencing central depression was reached. 
However theoretical may be the credentials of the diagonal that divides Fig. 7, and however oversimplified the foregoing example, the plotted increases of ventilation do run to an interesting degree parallel with the diagonal. The regression line is of slightly lesser inclination; but this in any case is inevitable, since at the higher levels of arterial oxygen tension the standard exercise does not call for such increases in ventilation as a stricter parallelism would require.

It is necessary, finally, to anticipate an obvious objection to the suggested role of severe anoxia in retarding the ventilatory responses. Even on evidence from our own supine-exercise tests with concurrent arterial sampling, it may be argued that after initial delay, adequate ventilation rates are ultimately achieved by these patients, in the face of anoxæmia by then more profound than during the initial retarded phase. To this it can only be answered that the hyperpnoea of exercise is known to involve mechanisms additional to those controlling ventilation at rest; and it is easily conceivable that the initial anoxic depression of the centre may be temporary or that it may be overcome when the humoral factors are sufficiently supplemented by whatever specific stimulus the exercise itself affords.

\section{SUMMARY}

The cardio-respiratory function of 32 patients with cyanotic congenital heart disease and 4 with pulmonary arterio-venous aneurysms was studied by cardiac catheterization and expired air collection, and the findings analysed to evaluate the mechanisms of adaptation to a central venous arterial shunt.

Resting oxygen uptake lay within the normal range predicted for the sex, age, and surface area of each patient.

A significant negative correlation existed between the hæmoglobin concentration and the resting effective pulmonary blood flow when the latter was expressed as the reciprocal of its arterio-venous oxygen difference. Analysis of the findings in 36 patients with the tetralogy of Fallot published by other workers confirmed this relationship.

Increased hæmoglobin concentration plays an important part in maintaining tissue oxygen tension at rest when the effective pulmonary blood flow is reduced to less than half normal because it enables oxygen uptake to be maintained without profound depression of the oxygen saturation and tension of the venous blood. During exercise of any given patient with a central venous-arterial shunt the maximum sustainable oxygen consumption can be regarded as directly proportional to the hæmoglobin content of the blood.

Increase in systemic blood flow is valueless as an adaptive mechanism unless accompanied by increase in effective pulmonary blood flow. Resting systemic flow varied widely from case to case, but the mean value for the group, expressed as the reciprocal of its arterio-venous oxygen difference, was normal.

The circulatory response to sustained exercise was studied in five patients. The effective pulmonary blood flow increased in all; the proportion of venous blood entering the lungs fell in three patients and rose in two. There was no apparent relationship between the findings at rest and the hæmodynamic response to effort.

Moderate or considerable resting hyperpnœa was present in all patients except a small minority in whom anoxæmia was either minimal or extreme. It was unrelated in its degree to any other single index of disability; but if arterial blood composition was considered as a whole and $\mathrm{CO}_{2}$ as well as $\mathrm{O}_{2}$ taken into account, a relationship became obvious. Gray's multiple-factor theory of respiratory control seemed to have the same validity of application to these patients as to normal subjects.

The respiratory response was studied during two forms of exercise. A standard one-minute step-exercise was performed by most of the patients. Observations were made on a smaller number of patients and normal subjects during exercise sustained until ventilation stabilized: this took at least twice as long for the patients as for the controls. The results of the one-minute exercise also revealed a delayed respiratory response. This seemed to be directly related to the severity of resting arterial anoxæmia. The relationship was linear if the resting anoxæmia was converted (by Gray's equation) into terms of " anoxic partial stimulus." 
Resting hyperpnœa, it is suggested, may in part constitute an insurance against the contingency of exercise; maintaining reserves of oxygen in the alveolar air, which can be consumed in the first minute or two of exercise before ventilation becomes adequate.

Our thanks are due to Mr. A. C. Pincock for invaluable technical assistance; and also to Dr. K. W. Donald, and to colleagues on the Staff of the United Birmingham Hospitals who referred cases for investigation. We acknowledge with gratitude financial grants from Messrs. I.C.I. Ltd., and from the Medical Endowment Fund of the United Birmingham Hospitals.

\section{REFERENCES}

Arnott, W. M., Cumming, G., Davison, P., and Pincock, A. (1951). J. Physiol., 113, 31P.

Baldwin, E. de F., Cournand, A., and Richards, D. W. (1949). Medicine, 28, 201.

Barcroft, J. (1934). Features in the Architecture of Physiological Function. University Press, Cambridge.

Bing, R. J., Vandam, L. D., and Gray, E. D. (1947a). Bull. Johns Hopkins Hosp., 80, 107.

- - $(1947 b)$. Bull. Johns Hopkins Hosp., 80, 121. , Hosp., 83, 439.

Blalock, A., and Taussig, H. B. (1945). J. Amer. med. Ass., 128, 189.

Boothby, W. M., and Sandiford, I. (1920). Laboratory Manual of the Techniques of Basal Metabolic Determinations. Philadelphia.

Brock, R. C., and Campbell, M. (1950). Brit. Heart J., 12, 377.

Burchell, H. B., Taylor, B. E., Knutson, J. R. B., and Wood, E. H. (1950). Circulation, 1, 404.

Cournand, A., Baldwin, E. de F., and Himmelstein, A. (1949). Cardiac Catheterization in Congenital Heart Disease. Commonwealth Fund. New York.

Dill, D. B. (1944). Nomograms in Handbook of Respiratory Data in Aviation. Office of Scientific Research and Development, Washington, D.C.

Ernsting, J., and Shephard, R. J. (1951). J. Physiol., 112, 332.

Fick, A. (1870). Sitzumgsb. d. phys. med. Gesellsch. zu Wurzburg, 16.

Gray, J. S. (1946). Science, 103, 739.

(1950). Pulmonary Ventilation and its Physiological Regulation. Springfield, Illinois.

Hamilton, W. F., Winslow, J. A., and Hamilton, W. F. Jr. (1950). J. clin. Invest., 29, 20.

Holling, H. E., and Zak, G. A. (1950). Brit. Heart J., 12, 153.

Houston, C. S., and Riley, R. L. (1947). Amer. J. Physiol., 149, 565.

Matheson, H. W., and Gray, J. S. (1950). J. clin. Invest., 29, 688.

Morse, M., Schlutz, F. W., and Cassels, D. E. (1949). J. Applied Physiol., 1, 683.

Van Slyke, D. D., and Neill, J. M. (1924). J. Biol. Chem., 61, 523. 